Accesed on: http://jkb.ub.ac.id/index.php/jkb/article/view/2749

Jurnal Kedokteran Brawijaya Vol. 31, No. 3, Februari 2021, pp. xxxx

Article History: Received 13 Juni 2020, Accepted 16 September 2021

Research Article

\title{
Reasons and Hindrances of the Community Leaders in Releasing Stocked Persons with Mental Problems in Southern East Sulawesi
}

\section{Alasan dan Hambatan Tokoh Masyarakat Dalam Melakukan Lepas Pasung pada Orang dengan Gangguan Jiwa di Sulawesi Tenggara}

\author{
Abdul Patawari ${ }^{1}$, Titin Andri $W^{2}$, Nurul Muslihah ${ }^{3}$, Asti Melani $A^{4}$, Yulian Wiji $U^{5}$ \\ ${ }^{1}$ Master of Nursing Study Program Faculty of Medicine Universitas Brawijaya Malang \\ ${ }^{2}$ Department of Nutritional Science Faculty of Medicine Universitas Brawijaya Malang \\ 3,4,5 Department of Nursing Faculty of Medicine Universitas Brawijaya Malang
}

\begin{abstract}
Undertaking stock punishment is an action to immobilized individuals that suffer mental health disorders. It is mostly done by placing woods on individuals' ankles. They are designed to restrict the patients' movements and made from wooden bars. The patients are chained or locked in a special room. A community leader, as the leader of certain people, has important roles in undertaking the stocks. It is done by considering various reasons based on the constructed understanding and emerging assumptions in the middle of society. This research aims to explore the reasons and hindrances of the community leader in releasing the stocks undertaken on individuals with mental health disorders. The applied research method is qualitative research with an interpretative phenomenology. 7 participants were selected by using purposive sampling. Then, an analysis was carried out by the Interpretative Phenomenological Analysis (IPA). The findings dealing with the reasons for the community leader to undertake the stocks consisted of two themes. They dealt with the administered medication to recover individuals with mental health disorders and to protect them, their families, and society. Meanwhile, the hindrances of the community leader in discharging or releasing the punishment dealt with the difficulty to get psychiatric service. The conclusions are the stocks reasons deal with a lack of the community leader's understanding to care for the individuals with mental health disorders and the necessity of active participation of medical officers. Thus, the people could obtain maximum psychiatric service
\end{abstract}

Keywords: Community leader, hindrance, stocks reason

\begin{abstract}
ABSTRAK
Pemasungan adalah tindakan yang digunakan untuk mengurangi pergerakan pada Orang dengan Gangguan Jiwa (ODGJ) dengan menggunakan kayu, dirancang khusus agar pasien tidak dapat bergerak seperti kayu balok, diikat dengan rantai atau di kurung dalam ruangan khusus. Tokoh masyarakat sebagai pemimpin turut mengambil peran dalam melakukan tindakan pasung. Tindakan ini dilakukan dengan berbagai alasan yang dibentuk dari pemahaman dan asumsi yang muncul di masyarakat. Tujuan penulisan penelitian ini adalah untuk mengeksplorasi alasan serta hambatan tokoh masyarakat dalam melakukan lepas pasung pada orang dengan gangguan jiwa. Metode yang peneliti gunakan adalah penelitan kualitatif dengan Interpretative fenomenologis. Partisipan sebanyak 7 (tujuh) orang yang dipilih dengan menggunakan pendekatan purposive sampling selanjutnya dianalisis dengan cara Interpretative Phenomenological Analysis (IPA). Hasil penelitian untuk alasan tokoh masyarakat dalam melakukan tindakan pasung ditemukan dua tema yaitu merasa pengobatan yang telah dilakukan tidak menyembuhkan ODGJ dan untuk melindungi ODGJ, keluarga dan masyarakat sedangkan hambatan tokoh masyarakat dalam melakukan lepas pasung ditemukan tema kesulitan memperoleh pelayanan kesehatan jiwa. Kesimpulan yaitu alasan tindakan pasung dilakukan karena kurangnya pengetahuan tokoh masyarakat terkait penanganan ODGJ yang tepat dan membutuhkan partsipasi aktif dari petugas kesehatan agar masyarakat mendapat layanan kesehatan yang maksimal
\end{abstract}

Kata Kunci: Alasan, hambatan, pasung, tokoh masyarakat

Correspondence: Abdul Patawari. Master of Nursing Study Program Faculty of Medicine Universitas Brawijaya Malang, Jl. Veteran Malang Tel.085254207388Email:abdulpatawaris.kep.ns@gmail.com

DOI: http://dx.doi.org/10.21776/ub.jkb.2021.031.03.X 


\section{INTRODUCTION}

Mental health disorder requires worldwide attention since the case rate gets higher. According to the World Health Organization (WHO), mental health disorder (MHD) sufferers have higher mortality and disability risks which is about $40 \%$ to $60 \%$. A suicidal case is the mortality cause in the adolescent period around the world (1). Indonesia has included as a high mortality and disability rate countries because of high schizophrenia cases than other countries in the world (2). According to the data of Indonesia Basic Health Research (Riskesdas), the occurrence of mental health problems in 2013 consisted of $1.7 \%$ per mill (3) with stocks occurrence percentage from $14.3 \%(4)$ and raised into $7.0 \%$ per mill in $2018(5,6)$. Riskesdas also notes that the stocks occurrence rate in 2018 was still $14 \%$. Then, from the numbers, there were still found $31.5 \%$ stocked individuals within the recent three months (7). The increasing rate of mental health problems, based on the data of Southern East Sulawesi public health office in 2018, was 1.787 individuals. Only about 1.147 individuals (64.19\%) received health services. From the data, it is found about 152 individuals suffering from mental health disorders are stocks punished. In August 2019, the rate of stocks increased to 161 individuals.

Undertaking stocks is an action to immobilize individuals that suffer mental health disorders. It is mostly done by placing woods on individual's ankles. They are designed to restrict the patient's movements and made from wooden bars. The patients are chained or locked in a special room $(4,5)$. Various reasons were uttered by the family when such action was undertaken on individuals with mental health disorders. The reasons are to prevent the sufferers to commit any harmful actions toward the sufferers or other people $(8,9)$, to prevent the sufferers from escaping home and committing suicide (10), and due to lack of knowledge to take care of them when they are snapped. Low economy and educational factors became the causes of the mental health disorder patients undertaken by the stocks (11).

The roles of community leaders in Southern East Sulawesi are so powerful, to manage the appropriate social behaviors to the applied norms and politeness. The participants who were trusted to be the community leaders because of their descendants, their knowledge, and their wisdom. Violating or breaking the applied regulations by the community leaders are assumed to offend all people in that area. According to Tohani, to create harmonious and humanist community would require the influences and positions of an informal leader (12). Mental health promotion in society requires the roles of a respected community leader in society (13). One of the roles is to release the mental health disorder individuals (MHDIs) by mediating and suggesting the families and the people (14).

According to the community leaders (formal leaders and the traditional figures), stocks are undertaken for any patient that is frequently snapped or mad. The purpose is to prevent further risk of damaging the environment, such as family and society safety. This action is done by the community leaders because they do not know about the treatment and recovery methods as well as the appropriate rehabilitation method for individuals with mental health disorders. Thus, it influences to lack of supports and medication actions (15). This research aims to explore the reasons and hindrances of the community leader in releasing the undertaken stocks on individuals with mental health disorders in Southern East Sulawesi.

\section{METHOD}

This research was performed qualitative method with the Interpretative Phenomenological Approach. In carrying out this research, the researchers explored the reasons of the community leaders and the families for undertaking the stocks and what hindrances they encountered while discharging the punishment.

The participants were selected from a population by applying purposive sampling. The numbers of the participants consisted of seven respondents. The inclusion criteria were 1) the community leaders had to stay in the research site, 2) they ever participated or being involved in any punishment discharging process, 3 ) the community leaders did not have any relationship with the patients, 4) the participants were willing to be respondents by signing up a consent form of becoming the participants, and 5) the participants were willing to be interviewed and recorded during the research process.

An in-depth interview was used to collect the information from the participants. The interview was based on a semistructured interview guideline. All conversations were recorded by using a recorder (a mobile phone) and futher analyzed with the Interpretative Phenomenological Analysis (IPA). The process was started by reading and rereading all verbatim transcripts of the interview results. Then, it was continued by finding out the keywords, clarifying the categories, determining the themes for each participant, and combining all founded themes of each participant into three themes.

\section{RESULTS}

The results presents the themes that was interpreted based on the utterances and the delivered statements by the community leaders. They dealt with the reasons and hindrances to discharge or release the stocks punished individuals. The themes consist of feeling that the already administered medication could not cure the individuals with a mental health disorder, protecting the individuals with MHD, their families, and the people, and having problems to get psychiatric services.

Theme 1: Feeling That the Already Administered Medication Could Not Cure the MHDI

Four participants stated that the mental-health disorder sufferers never got medical medication. They got treatment from medicasters, religious seniors, or clerics. The participants also stated that the health conditions of the patients got worsened after being treated by the medicasters. That was the reason the MHDI lived stocks punished. Here are the excerpts of the participants:

"They never got medication from any hospitals... They only got treatment from medicaster" (R1)

"The three of them did not show any better changes... Their conditions are even getting worse... Because they strayed, got angry, snapped, or even mad. They were going mad on the street. They pelted other people's houses (R1)

"You know. They were brought and sprayed out by the 
water. They were asked to drink it. However, there were no differences. They were getting mad. I was afraid to get closer since I was usually spat on... Thus, he was stocks punished" (R2)

"Sometimes...I did not know... Perhaps it was kind of suggestion or somewhat... Because it was what the people said... They said the patients would be recovered... Usually, it would take one or two days... However, mostly the results raised to rage (R4)

"... It was doubled... How should I say - getting worse... It was getting worse... They did not get medication. It was because they seemed like medicasters or religious seniors" (R5).

Theme 2. Protecting the MHDI, Their Families, and the People

The participants stated that the purpose of undertaking stocks was to secure the family and people from the sufferers that tended to go in rage and tend to harm other people. The stocks were undertaken because of the sufferers' actions. Their actions were troubling so the people could not allow such actions to occur anymore. Thus, the community leaders suggested the families charge them in stocks. This theme is arranged from several themes as follow:

\section{Protecting MHDI}

Two participants stated that the patients frequently escaped without being noticed by the families. Thus, to protect them from any dangerous matters, they were undertaken in stocks. Here are the excerpts of the participants:

It led him to charge his mother in stocks... She usually opened the window... She escaped from the window and went somewhere... We ever searched for her and we found her in Mowila... We also ever tried to search her and we found her in Mokoawu..... He called and told that one of his family members had gone missing... You know, some of us were also busy" (R3)

She ran around... That made us afraid... We were afraid if something harmed her... She was still just a girl.... It ever made us tie her on a house pillar... To keephernot escaping..." (R5)

\section{Protecting the Family}

The participants suggested that all sharp objects were hidden because they could have been used by the MHDI to harm other people. Here are the excerpts of the participants.

"...Let's say the sharp objects... Let's hide them... Do not let the objects on his hand... You know someone like that... For the sake of safety..... That was the most important, his safety... Meanwhile, dealing with his dietary habit...Although he was hungry..... He did not want to eat... It should be his parents' jobs... And when he went to sleep, all sharp objects should be hidden... It made his parents stayed alert while sleeping... You know he ever hit... Thus, he was locked up" $(R 5)$

\section{Protecting the Citizens}

The MHDIs were sometimes in rage and disturbed other people. Therefore, the participants should charge them in stocks to protect other people from the MHDIs' behaviors. Here are the excerpts of the participants:
"To charge in stocks has a purpose to make this individual... The patient, the people... To not go in rage, to not harm other people, thus this person should be secured... The stocks charge has a purpose to secure such persons" (R1).

"Ummm, for me... To charge an individual in stocks is about a mentally ill patient, sir... Because the purpose to charge in stocks is to prevent such persons from harming other people" (R2).

"That's it... Therefore, what he was afraid of was his family would injure other people... and other families too..."(R4)

"Since there is no one wants to take care... Thus, his parents decided to tie him since he would harm other people" (R6)

\section{Theme 3. Having Difficulties to Get psychiatric Service}

In terms of the research context, the meaning of having difficulty to get psychiatric service deals with all hindrances experienced by the patients, the families, and the people in getting the psychiatric services. This theme was arranged from several sub-themes as follow:

Lack of Attention of the Officers for the Mental-Health Disorder Patients

Two participants stated that the health officers in the health center did not respect the patients with mental health disorders. According to the participants, the officers only served any mental-health disorder patients if there was a report from the local people. Thus, a community leader thought that the health center officers were not sensitive to these mental-health disorder individuals. Here are the excerpts of the participants:

"It is... Here to fore, the health center men did not care about such disorder... They did not pay attention to it..." (R4)

"When I deals with such disease, I try to look at the health center performance... You know... it is still....still poor" (R6)

"It is poor because I see they do not have any sensitivity" (R6).

The Unavailability of Mental Medicine in the Health Center

The participants said that the families had brought the patients to the health center. However, they had difficulties to get the service because the medicine for MHDIs was not available. Thus, the MHDI could be snapped once the medicine ran out. Here are the excerpts of the participants:

"It also happens in the Health Center... They said there was no mental medicine in the health center... I do not know what kind of medicines the health center provides... They just said the medicines were not available there" $(R 2)$

\section{The Complex Regulations to Get Health Service}

The participants stated that the people had difficulties to get psychiatric service because they thought the regulation was complex and burdened the patients. The participants also stated that to get a psychiatric service, they had to prepare several files while medicating. However, they did not know how to handle the filing. Here are the excerpts of the participants: 
"You know, the regulation burdens the people... It is true..." (R3)

To join the Social Security Administrator membership, they do not know how to do..." (R7)

\section{DISCUSSION}

Theme 1: Feeling That the Already Administered Medication Could Not Cure the MHDI

The community leaders perceive and understand the care and medication for MHDIs differently. The participants said that they did not know about mental health disorders. Thus, it made them confused about what to do. The participants perceived that medicaster medication and stocks were the best options to take care of the MHDIs that frequently disturbed other people. Confusion, meant in this research, has correlations to the participants' and the people's knowledge about the disease and how to deal with MHDIs. According to Yancen in Hasanah, insufficient knowledge would influence the spontaneous actions that negatively impact MHDIs. Insufficient knowledge also causes health care administration slow (16). It is due to the people's misconceptions such as arguing that mental health disorder is a curse, a punishment, and supernatural interruption (9).

The applied medication for MHDIs is considered as an alternative. It is such as a medicaster and it puts aside medical medication. The results of such medication cause the worsening condition of the patients. Palupi, Ririanty, and Nafikadini, state that inappropriate medication occurs due to the tendency of the family to choose medications from medicasters, religious seniors, flower bathing, sacrificing animals, ruqiyah, or purchasing medicines at shops, even undertaking the stocks (17). It was done because of the assumption that mental health disorder was caused by psychosocial problems and supernatural problems due to spirits (sorcery) (18). Thus, the medication method tended to seek for alternatives from the community and religious leaders (19). This research is consistent with the statement from Labys, Susser, and Burns (13). They stated that in seeking the assistance of mental health, the people in Southern Africa tended to take informal sources, such as traditional or religious leaders. More than two-thirds of the people ever visited hospitals and only 1 from 8 persons accessed the asylum. Thus, the patients' medications were not maximum. Abera et al., stated that about $92.7 \%$ of the family struggled to get the medications from the religious seniors or supernatural experts. It was based on what they believed in (20).

The process of obtaining the medication also depended on the responses from the health workers. Many patients thought they were treated differently especially when the disease they suffered had something to do with drug abuse and mental disorder. According to Hothasian, Suryawati, and Fatmasari, they concluded that the mental health program implementation in a Health Center had not been optimal (21). There were still $5.3 \%$ of the sufferers who had not obtained the appropriate care. Besides the low economic factor of the family that was dissatisfied with the service availability, lack of socialization in a society by the health workers caused misconceptions in a society growing $(22,23)$. The health professional workers had negative attitudes toward any patients with drug abuse records who suffered mental disorders. They thought the patients could commit any harm and not cooperative so that it hindered the service administration. There was also a lack of empathy from the health workers $(19,20)$.

According to Lestari, charging stocks for the MHDIs had been committed by caregivers because it was considered as a therapy. Besides that, there was also a suggestion from the community leaders (the traditional figures or medicasters) that became the primary reason for a family to charge the stocks. This statement is strengthened by a study from Puteh, Marthoenis, and Minas (24). They stated that there were $86.4 \%$ of stock decisions were done by the families and the remaining percentage, $13.6 \%$, was done by the community leader's decision.

\section{Theme 2: Protecting the MHDI, Their Families, and People}

The stocks undertaken by the community leaders had reasons to keep the MHDIs' families and the surrounding society secured from the MHDIs' behaviors since the behaviors were deemed dangerous. The behaviors performed by the MHDIs were such as raging, beating, getting angry, and harming other people. Thus, they were treated specifically because the actions could harm the patients, other people, and the environment. To protect, in this research, is an effort done by the community leaders to prevent the MHDIs from harming their families and the people.

The harmful behavior became a feature of the MHDIs that made the community leaders struggled to administer their medication as anticipation toward any worsening result in the future days. According to Buchanan et al., about 5.4\% of mental health disorder sufferers were reported to ever commit any violence and disadvantage actions upon the medication follow up. 8.3\% of them ever committed violences but they did not harm other people. It was caused due to the harmful behaviors at the beginning of their illness, severity level, drug abuse, sexual abuse, and non-compliant treatment. Thus, they were considered to put other individuals at disadvantages (25).

The violence committed by the MHDIS would cause perceptions from the families and the surrounding people. They were described as a stigma or negativeness. Such internalized negative stigma would influence social supports and interactions. Thus, it would worsen the social functions and worsen the mental-health disorder patients' conditions. A stigma would also determine administered care (26). According to Laila et al., they similarly stated that family, society, and community leader assumed undertaking stocks was promoted for the sake of the shared security because of the MHDIs dangerous behaviors. Furthermore, findings of research conducted in Aceh showed $79.7 \%$ of stocks occurrences were done due to aggressiveness and dangerous actions committed by MHDIs (27).

According to the people and community leaders, undertaking the stocks was used to reduce the environmental risk due to the MHDIs' behaviors that were considered disturbing the shared security of the families and the people (15). This statement is strengthened by a study of Laila et al., in Bogor. They stated that the reasons dealt with security issues due to the aggressiveness and dangerous behaviors, such as going to rage, harm other people, taking other people's meals and belongings that made the families, people, and community leaders undertook and deemed the stocks important for mental 
disorder sufferers (27).

\section{Theme 3: Having Difficulties to Get Psychiatric Service}

This theme was experienced by the participants due to the encountered hindrances by their families, people, and participants when they brought the MHDIs to be checked up and receive psychiatric service in the health facility. The participants felt that the ways the psychiatric service administered their service for the MHDIs in the health center was still very poor. It was due to the uneven medicine distribution for the mental health disorder sufferers even the absence of such medicine in the health center. This difficulty was experienced not only in terms of medicine availability but also the therapy for the patients. The health workers in the health center were also considered to not fully pay attention to mental health disorders. The participants argued that the health workers were not sensitive toward the sufferers and the families. The participants even felt that the psychiatric service was not like other illness services.

The difficulties to get the health service that was triggered by the health workers made them disappointed. Their disappointments, as referred to in this research, were dissatisfaction feelings toward what they had expected from the health workers and the health center. The fact was they could not meet the necessities of the participants, the clients, the families, and the people. Based on the findings of research conducted by Hothasian, Suryawati, and Fatmasari, in Bandharjo, Semarang, it concluded that the implementation of the mental health program in the health center had not been optimum. There was $5.3 \%$ of the sufferers had not the appropriate care. It was caused by a lack of the mentalhealth standard operational procedure implementation, medicine limitedness, and in-proactive performance of the health center workers in promoting early detection. Besides the low economic factor of the family that was dissatisfied with the service availability, lack of socialization in a society by the health workers caused misconceptions in the society to keep growing $(21,22)$.

A family, as the caregiver, felt difficult to obtain psychiatric service. It was due to low economic factors, lack of health insurance ownership, and the assumption of burdening health regulation for the clients and families. The participants stated that most of the sufferers with a mental disorder had low economic statuses. The expensive cost of the mental medicine, its complex access to get, and lack of health insurance ownership made the MHDIs did not receive psychiatric service. Habtamu, Alem, Medhin, Fekadu, and Hanlon, stated that the encountered hindrances by the families as the caregivers in fulfilling the medication demands could be influenced by the ages of the caregivers, their remote domiciles from the health services, poor economic statuses, bad stigma, and worsening symptoms (28).

According to the participants, the hindrances were

\section{REFERENCES}

1. World Health Organization. Mental Health Action Plan 2013-2020. Geneva: WHO; 2013.

2. Brooks H, James K, Irmansyah I, et al. Exploring the Potential of Civic Engagement to Strengthen Mental Health Systems in Indonesia (IGNITE): A Study emotionally and mentally draining because of various considerations. However, the considerations did not give any chances for the MHDIs to get health facilities. Longer care and expensive cost were the burdens of the families as the caregivers (29). This statement is strengthened by Astuti. In her research, it was found that low economic factors caused the family could not provide and facilitate the MHDIs to receive proper medications (30). Such perspectives would cause the clients and families to avoid and deny the medication, assistance, and feel inferior so their efforts might turn to commit suicide (31).

According to Hermiati and Harahap, the precipitation factors of the mental-health disorder occurrence could be caused by the emotional level of the families (emotional turbulent families), stressful life events, discrimination committed by surrounding people, and poverty factor (32). A similar statement is also stated by Hothasian et al. It was stated that the economic factor became the cause that patients did not receive psychiatric services. Furthermore, they also stated that the applied regulation by the government health service provider, such as the referral was considered as a burden for the patients and their families (21). Those difficulties to receive health services for mental-health disorder sufferers influenced the spirits and motivations of the MHDIs to get developed in society. Meanwhile, it was found that motivation and spirit could improve optimism, life quality, and life satisfaction of the mental-health disorder sufferers. Higher optimism could implicate to the administered intervention. Thus, the MHDIs would be more productive, such as by working and relieving their stresses (33).

Several reasons for the community leaders to get involved in undertaking the stocks for MHDIs were due to the medication efforts of the families. The efforts did not have any significant influence so to protect the clients, families, and the people, the community leaders assumed undertaking the stocks was the correct option. Besides that, the community leaders felt difficult to get psychiatric service because the health workers did not care. There were absences of the mental medicine in the health center and the regulation service was considered burdening the people so the families could not provide sufficient medications.

\section{CONFLICT OF INTEREST}

No conflict of interest

\section{SOURCE OF FUNDING}

This research took personal financing.

\section{ETHICAL CLEARANCE}

This research was conducted after obtaining the permission of the Ethics Commission of Makassar Health Polytechnic. 0011/KEPK-PTKMKS/I / 2020.
Protocol. International Journal of Mental Health Systems. 2018; b12(1): b1-10.

3. Riyana D and Kisworo B. Intervensi Pekerja Sosial terhadap Penyandang Disabilitas Mental di Margo Laras Pati. Journal of Nonformal Education and Community Empowerment. 2019; 3(1): 79-87. 
4. Daulima NHC, Rasmawati R, and Wardani IY. Penurunan Kemampuan Kepala Keluarga dalam Memenuhi Kebutuhan Ekonomi Keluarga: Studi Fenomenologi Pengalaman Orang dengan Gangguan Jiwa Paska Pasung. J Keperawatan Indones. 2019; 22(2): 139-146.

5. Sulistyowati EC and Sulistywi D. Pemberdayaan Pasien dengan Pendekatan Self Help Group terhadap Perubahan Mekanisme Koping pada Pasien Gangguan Jiwa Skizofrenia di RSJD Dr Arif Z Surakarta. Interest Jurnal Ilmu Kesehatan. 2019; 8(1): 94-100.

6. Dewi El, Wuryaningsih EW, and Susanto T. Stigma Against People with Severe Mental Disorder (PSMD) with Confinement "Pemasungan". NurseLine Journal. 2019; 4(2): 131-138.

7. Dewi AR, Daulima NHC, and Wardani IY. Hubungan Karakteristik Keluarga terhadap Intensi Keputusan Pasung pada Keluarga dengan Gangguan Jiwa. Jurnal Keperawatan Widya Gantari Indonesia. 2020; 4(1): 52-58.

8. Yusuf A, Tristiana RD, and Purwo IMS. Fenomena Pasung dan Dukungan Keluarga terhadap Pasien Gangguan Jiwa Pasca Pasung. Jurnal Keperawatan Padjadjaran. 2017; 5(3): 302-306.

9. Lestari W and Wardhani YF. Stigma and Management on People with Severe Mental Disorders with "Pasung" (Physical restraint). Buletin Penelitian Sistem Kesehatan. 2014; 17(2): 157-166.

10. Setiawan L. Studi Fenomenologi: Pengalaman Keluarga Dalam Merawat Anggota Keluarga yang Mengalami Gangguan Jiwa. Jurnal Kesehatan Mesencephalon. 2018; 4(2): 57-66.

11. Suharto B. Budaya Pasung dan Dampak Yuridis Sosiologis (Studi tentang Upaya Pelepasan Pasung dan Pencegahan Tindakan Pemasungan di Kabupaten Wonogiri). Indonesian Journal of Medical Science. 2014; 1(2): 1-10.

12. Tohani E. Kapasitas Kultural Pemimpin Informal dalam Mewujudkan Masyarakat Harmonis. DIKLUS Jurnal Pendidikan Luar Sekolah. 2012; 16(2): 180192.

13. Labys CA, Susser E, and Burns JK. Psychosis and HelpSeeking Behavior in Rural Kwazulu Natal: Unearthing Local Insights. International Journal of Mental Health Systems. 2016; 10(1): 1-12.

14. Drown C, Harding $\mathrm{T}$, and Marshall R. Nurse Perceptions of the Use of Seclusion in Mental Health Inpatient Facilities: Have Attitudes to Māori Changed? The Journal of Mental Health Training, Education and Practice. 2018; 13(2): 100-111.

15. Husmiati, Irmayani NR, Sugiyanto, and Habibullah. Support for Mental Disability as a Strategy Supporting to Stop Pemasungan Program 2019. Sosio Konsepsia Jurnal Peneitian dan Pengembangan Kesejahteraan Sosial. 2017; 7(1): 62-74.

16. Hasanah U. Pengaruh Penyuluhan Kesehatan terhadap Perubahan Pengetahuan dan Sikap Masyarakat pada Penderita Gangguan Jiwa. Jurnal Keperawatan Jiwa. 2019; 7(1): 87-94.
17. Palupi DN, Ririanty M, and Nafikadini I. Karakteristik Keluarga ODGJ dan Kepesertaan JKN Hubungannya dengan Tindakan Pencarian Pengobatan bagi ODGJ. Jurnal Kesehatan. 2019; 7(2): 82-92.

18. Ventevogel $\mathrm{P}$, Jordans $\mathrm{M}$, Reis $\mathrm{R}$, and De Jong J. Madness or Sadness? Local Concepts of Mental IIIness in Four Conflict-Affected African Communities. Conflict and Health. 2013; 7(1): 116.

19. Khoury NM, Kaiser BN, Keys HM, Brewster ART, Kohrt BA. Explanatory Models and Mental Health Treatment: is Vodou an Obstacle to Psychiatric Treatment in Rural Haiti? Culture, Medicine and Psychiatry. 2012; 36(3): 514-534.

20. Abera M, Robbins JM, and Tesfaye M. Parents' Perception of Child and Adolescent Mental Health Problems and Their Choice of Treatment Option in Southwest Ethiopia. Child \& Adolescent Psychiatry \& Mental Health. 2015; 9(1): 1-11.

21. Hothasian JM, Suryawati C, and Fatmasari EY. Evaluasi Pelaksanaan Program Upaya Kesehatan Jiwa di Puskesmas Bandarharjo Kota Semarang Tahun 2018. Jurnal Kesehatan Masyarakat. 2019; 7(1): 75-83.

22. Laila $\mathrm{NH}$, Mahkota $\mathrm{R}$, Krianto $\mathrm{T}$, and Shivalli $\mathrm{S}$. Perceptions about Pasung (Physical Restraint and Confinement) of Schizophrenia Patients: $A$ Qualitative Study among Family Members and Other Key Stakeholders in Bogor Regency, West Java Province, Indonesia 2017. International Journal of Mental Health Systems. 2018; 12(1): 1-7.

23. Van Boekel LC, Brouwers EPM, Van Weeghel J, and Garretsen HFL. Stigma among Health Professionals towards Patients with Substance Use Disorders and Its Consequences for Healthcare Delivery: Systematic Review. Drug and Alcohol Dependence. 2013; 131(1-3): 23-35.

24. Puteh I, Marthoenis M, and Minas H. Aceh Free Pasung: Releasing the Mentally III from Physical Restraint. International Journal of Mental Health Systems. 2011; 5: 1-5.

25. Buchanan A, Sint K, Swanson J, and Rosenheck R. Correlates of Future Violence in People Being Treated for Schizophrenia. The American Journal of Psychiatry. 2019; 176(9): 694-701.

26. Zhang $\mathrm{TM}$, Wong IYL, $\mathrm{Yu} \mathrm{YH}$, et al. An Integrative Model of Internalized Stigma and Recovery-Related Outcomes among People Diagnosed wth Schizophrenia in Rural China. Social Psychiatry and Psychiatric Epidemiology. 2019; 54(8): 911-918.

27. Laila NH, Mahkota R, Shivalli S, Bantas K, and Krianto T. Factors Associated with Pasung (Physical Restraint and Confinement) of Schizophrenia Patients in Bogor Regency, West Java Province, Indonesia 2017. BioMed Center Psychiatry. 2019; 19: 1-8.

28. Habtamu K, Alem A, Medhin G, Fekadu A, and Hanlon C. Functional Impairment among People with Severe and Enduring Mental Disorder in Rural Ethiopia: A Cross-Sectional Study. Social Psychiatry and Psychiatric Epidemiology. 2018; 53(8): 803-814.

29. Chakrabarti S. Research on Family Caregiving for Mental Illness in India and Its Impact on Clinical 
Practice: Are We Doing Enough to Help Families? Indian Journal of Social Psychiatry. 2016; 32(1): 1924.

30. Astuti M. Kondisi Orang dengan Gangguan Jiwa Pasung, Keluarga dan Masyarakat Lingkungannya di Kabupaten 50 Kota. Sosio Konsepsia Jurnal Peneitian dan Pengembangan Kesejahteraan Sosial. 2017; 6(3): 256-268.

31. Zhang Z, Sun K, Jatchavala C, et al. Overview of Stigma Against Psychiatric Illnesses and Advancements of Anti-Stigma Activities in Six Asian
Societies. International Journal of Environmental Research and Public Health. 2020; 17(1); 1-23.

32. Hermiati D and Harahap RM. Faktor yang Berhubungan dengan Kasus Skizofrenia pada Pasien Rawat Inap Rumah Sakit Khusus Jiwa Soeprapto Provinsi Bengkulu. Jurnal Keperawatan Silampari. 2018; 1(2): 78-92.

33. Seo MA and Lim YJ. Optimism and Life Satisfaction in Persons with Schizophrenia Living in the Community. The International Journal of Social Psychiatry. 2019; 65(7-8): 615-620 